\title{
THE EFFECT OF SALINITY ON THE GROWTH OF THE HALOPHYTE ATRIPLEX HORTENSIS (CHENOPODIACEAE)
}

\author{
S. SAI KACHOUT ${ }^{1}$ - A. Ben MANSOURA ${ }^{2}-$ K. JAFFEL $^{1}$ - J.C. LECLERC ${ }^{3}-$ M.N. REJEB ${ }^{2}-$ Z. \\ OUERGHI ${ }^{1}$ \\ ${ }^{1}$ Laboratoire de physiologie végétale, faculté des sciences de Tunis, campus universitaire, \\ Tunisie \\ ${ }^{2}$ Institut National de Recherche en Génie Rural, Eaux et Forêts (INRGREF), Tunisie ${ }^{3}$ Equipe \\ d'Ecophysiologie Appliquée Faculté de Sciences et Techniques Saint Etienne, France \\ *Corresponding author \\ e-mail:salmasey@yahoo.fr \\ (Received $16^{\text {th }}$ June 2009 ; accepted $14^{\text {th }}$ December 2009)
}

\begin{abstract}
The effect of salt stress on the growth of the Atriplex hortensis was determined by growing plants in soils receiving a one-time irrigation of nutrient solution containing low, medium, and high levels of $\mathrm{NaCl}$. Atriplex plants were grown in sand culture under controlled greenhouse conditions. The experiment was compared to two varieties of A. hortensis. Growth and yield were progressively declined by increasing $\mathrm{NaCl}$ concentrations. Atriplex hortensis, an annual halophyte, exhibits significant reduction in height and biomass under saline stress conditions. The photosynthetic activity decreases when plants are grown under saline conditions leading to reduced growth and productivity. Low levels of salinity (5 $\mathrm{g} / \mathrm{l} \mathrm{NaCl}$ ) did not cause substantial inhibition of growth but increasing concentrations of salt induced a progressive decline in length and weight of the plants. Salt stress induced a significant decrease in leaf area, but it had no significant effect on leaf water content. The results of present study indicate no differences in salinity tolerance in both Atriplex plants. Another possible conclusion is that improved tolerance to salt stress may be accomplished by decline in growth and photosynthetic activity. Based on these findings the tolerant Atriplex can be grown in moderately $\mathrm{NaCl}$-contaminated soils.

Keywords: Atriplex; salt stress; biomass production; chlorophyll concentration; water content; stomatal conductance.
\end{abstract}

\section{Introduction}

Salinity is one of the most important environmental factors limiting crop production of marginal agricultural soils in many parts of the world. Salinity effects on plants include ion toxicity, osmotic stress, mineral deficiencies, physiological and biochemical perturbations, and combinations of these stresses [31, 67, 68, 74, 102]. Salt ion toxicity has numerous deleterious effects on plants such as denaturing cytosolic enzymes [68]. Many investigations on quantification of salt tolerance of plant species have been based on experiments in which $\mathrm{NaCl}$ was the predominant salt $[18,42,44]$. Salt stress affects many aspects of plant metabolism and, as a result, growth and yields are reduced. Excess salt in the soil solution may adversely affect plant growth either through osmotic inhibition of water uptake by roots or specific ion effects. High concentrations of salts have detrimental effects on plant growth [23, 63] and excessive concentrations kill growing plants [20]. Halophytes are distinguished from glycophytes by their tolerance of saline conditions. The use of halophytic plants in pasture and fodder production on saline soils is the only economically feasible solution available [40]. Halophytes are plants that grow naturally in saline environments, such as salt marshes, salt spans and salt deserts [36]. Halophytic species differ widely in the extent to which they 
accumulate ions and their overall degree of salt tolerance [25, 26]. Atriplex species (saltbushes) are dominant in many arid and semi-arid regions of the world, particularly in habitats that combine relatively high soil salinity with aridity [60, 75, 77]. Several species belonging to the genus Atriplex are well adapted to harsh environmental conditions and therefore constitute a useful material for the identification of physiological mechanisms and genes involved in abiotic stress resistance [14, 90, 100]. Atriplex is a halophyte saltbush species highly resistant to drought [50], salinity [7], and heavy-metal stress [55]. Atriplex spp. are among a group of halophytes that complete their life cycle at high salinity levels and have the ability to accumulate high concentrations of micronutrients much greater than the required minimum $[82,101]$. Atriplex spp. has increased biomass production with salt increments in the growth medium ranging from 5 to $10 \mathrm{~g} \mathrm{l}^{-1} \mathrm{NaCl}[41,72]$. A similar promotion of growth has also been reported for other halophytic species $[9,18]$.

It is suggested that Atriplex spp. may be more suitable for revegetating very saline soils and also be a good source of productive feed [33, 76].

These plants could be promising, since Atriplex species have special bladders in the leaves that act as salt sinks for the removal of the excess of salt [47]. In the arid zones and other dry lands, halophytic plants often dominate because of their tolerance to drought and salinity [24]. Atriplex spp. are among the most salt-tolerant higher plants. They have adapted to salinity by tolerating salts internally and/or by excreting salt [41, 62]. However, the presence of high salt levels does not seem to be required for optimal growth. It is reported that soil salinity suppresses shoot growth more than the root growth [57, 81]. [23] reported that salinity causes reduction in leaf area as well as in rate of photosynthesis, which together result in reduced crop growth and yield. Also, high concentration of salt tends to slow down or stop root elongation [45] and causes reduction in root production [23].

In general, low salinity levels do not appear to have a deleterious effect on the growth of Atriplex spp. and may actually stimulate growth [3, 15, 59, 104]. However, high salinity levels may cause a reduction in total growth of Atriplex spp., especially in leaf biomass [6, 28, 66, 80, 85, 95, 97].

In this research, growth parameters such as dry mass, leaf area, plant height and root elongation of Atriplex plant were determined in order to get a general view of the effects of salinity on the overall growth of A. hortensis. Chlorophyll concentration, water content and stomatal conductance of plants were measured in order to understand how salinity affects the physiology of plants. Among Chenopodiaceae the genus Atriplex is the most studied, probably because Atriplex species are used for rehabilitation of saline soils.

\section{Materials and Methods}

\section{Plants}

Seeds of Atriplex hortensis were taken from a botanic garden: Denmark House, Pymoor, Ely, Cambridgeshire (CN seeds). Plants were grown in a greenhouse at 28/20 ${ }^{\circ} \mathrm{C}$ (day/night) under a photoperiod of $16 \mathrm{~h}$.

Atriplex seeds were planted in pots of $14 \mathrm{~cm}$ diameter and $25 \mathrm{~cm}$ depth; each pot contained $3,5 \mathrm{~kg}$ soil. The soil characteristics were as follows: sandy loam in texture, sand $52.3 \%$; silt $10.5 \%$; clay $12 \%$; pH 8.75 and organic matter $1.5 \%$. Ten seeds per pot 
and six replicates were used for each treatment. Irrigation was applied on a two days basis to achieve soil water field capacity level. Treatments were as follows:

Control and Salt Treatment:

a- control $(0 \mathrm{NaCl})$ b- $5 \mathrm{~g} / \mathrm{l} \mathrm{NaCl}$

c- $10 \mathrm{~g} / \mathrm{l} \mathrm{NaCl} \mathrm{d}-15 \mathrm{~g} / \mathrm{l} \mathrm{NaCl}$

\section{Growth parameters of Atriplex}

The plant height $(\mathrm{cm})$, root system length $(\mathrm{cm})$ and leaf area $\left(\mathrm{cm}^{2}\right)$ were measured (after 3 months). Plants were washed with distilled water and separated into shoots and roots. The dry weight $(\mathrm{dw})$ was obtained after oven drying the plants at $60{ }^{\circ} \mathrm{C}$ for 48 hours. The dry weights of the root and shoot systems were also determined.

The effect of salinity on physiology parameters was studied in terms of water content, chlorophyll concentration and stomatal conductance.

\section{Plant pigments}

Chlorophyll a and b were estimated spectrophotometrically [64], after acetone extraction of the pigments from fresh leaves. Chlorophyll concentration was determined with four replicate plants. A leaf sample of $0.1 \mathrm{~g}$ was ground and extracted with $5 \mathrm{~mL}$ of $80 \%(\mathrm{v} / \mathrm{v})$ acetone in the dark. The slurry was filtered and absorbancies were determined at 645 and $663 \mathrm{~nm}$.

\section{Statistical Analysis}

The pot experiment was set up in randomized complete block design replicated five times. ANOVA (SAS version 10.0) was employed for statistical analysis of data. Statistical significance was defined as $\mathrm{P}<0.05$

\section{Results}

\section{Effect of salinity on leaf growth}

Increasing $\mathrm{NaCl}$ concentrations in the irrigation solution significantly decreased total leaf area of both Atriplex varieties (Fig. 1). The leaf area of both varieties was nearly equal concentration in green and red, respectively. At $15 \mathrm{~g} / \mathrm{l} \mathrm{NaCl}$ total leaf area was reduced by $13 \%$ (red) and $47 \%$ (green) compared with the controls.

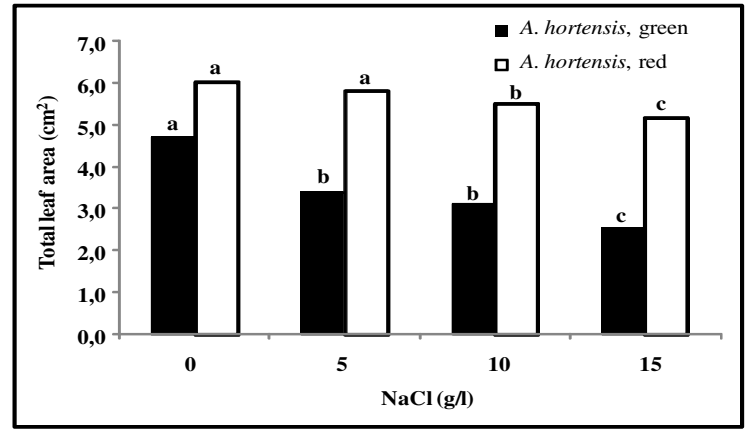

Figure 1. The effect of salinity on total leaf area in the two Atriplex varieties green and red. Different letters represent a significant difference $(P<0.05)$ between treatment

\section{Effect of salinity on dry weight}


Shoot dry weights at all stages of development were reduced progressively with increasing $\mathrm{NaCl}$ concentrations while reversibly.

Increasing concentration of salt in soil significantly retarded $(\mathrm{p}<0.05)$ dry weight of stems and roots (Table. 1). Dry weight significantly decreased $(\mathrm{p}<0.05)$ for shoots (leaves + stems), roots and total biomass of plants in response to increasing concentration of salt (Table. 1). Percentage relative weight of tissues of salinized plants compared to those of control plants were computed as (salinized tissue dry weight/control dry weight) x100. Dry weight values of tissues given in Tab. 1 were used for the calculation of percentage relative weight of tissues. Values of percentage relative weight varied from 88 to $52 \%$ for shoots, from 80 to $39 \%$ for roots and from 87 to 50 $\%$ for total biomass in response to increasing soil salinity from 5 to $15 \mathrm{~g} / \mathrm{l}$. In experiment, dry plant weight decreased dramatically with the increasing $\mathrm{NaCl}$ concentration. The greatest dry plant weight of Atriplex was obtained with the first treatment in all range of salinity treatments. The general tendency was that increasing concentrations of salt induced a progressive decline in the length of shoots and in the weight of roots, stems and leaves.

Table 1. Effect of salinity on root and shoot dry weights of Atriplex hortensis. Different letters represent a significant difference $(P<0.05)$ between treatments.

\begin{tabular}{|c|c|c|c|c|c|c|}
\hline \multirow{2}{*}{ Treatment } & \multicolumn{2}{|c|}{ Shoot } & \multicolumn{2}{|c|}{ Root } & \multicolumn{2}{|c|}{ Total weight } \\
\hline & (g/plant) & $(\%)$ & (g/plant) & $(\%)$ & (g/plant) & $(\%)$ \\
\hline \multicolumn{7}{|c|}{ A hortensis varieties green } \\
\hline $0 \mathrm{~g} \mathrm{NaCl} / 1$ & $14,545 \mathrm{a}$ & 100 & $2,253 \mathrm{a}$ & 100 & $16,798 \mathrm{a}$ & 100 \\
\hline $5 \mathrm{~g} \mathrm{NaCl} / 1$ & $12,838 \mathrm{~b}$ & 88 & $1,758 \mathrm{~b}$ & 78 & $14,596 \mathrm{~b}$ & 87 \\
\hline $10 \mathrm{~g} \mathrm{Nacl} / \mathrm{l}$ & $9,702 \mathrm{c}$ & 67 & $1,295 \mathrm{c}$ & 57 & $10,997 \mathrm{c}$ & 65 \\
\hline $15 \mathrm{~g} \mathrm{NaCl} / 1$ & $7,538 \mathrm{~d}$ & 52 & $0,889 \mathrm{~d}$ & 39 & $8,426 \mathrm{~d}$ & 50 \\
\hline $\mathrm{LDS}_{0,05}$ & 0,278 & - & 0,066 & - & 0,271 & - \\
\hline \multicolumn{7}{|c|}{ A hortensis varieties red } \\
\hline $0 \mathrm{~g} \mathrm{NaCl} / \mathrm{l}$ & $14,355 \mathrm{a}$ & 100 & $2,091 \mathrm{a}$ & 100 & $16,447 \mathrm{a}$ & 100 \\
\hline $5 \mathrm{~g} \mathrm{NaCl} / 1$ & $12,538 \mathrm{~b}$ & 87 & $1,680 \mathrm{~b}$ & 80 & $14,218 \mathrm{~b}$ & 86 \\
\hline $10 \mathrm{~g} \mathrm{Nacl} / 1$ & $10,139 \mathrm{c}$ & 71 & $1,301 \mathrm{c}$ & 62 & $11,440 \mathrm{c}$ & 70 \\
\hline $15 \mathrm{~g} \mathrm{NaCl} / 1$ & $7,460 \mathrm{~d}$ & 52 & $0,936 \mathrm{~d}$ & 45 & $8,396 \mathrm{~d}$ & 51 \\
\hline $\mathrm{LDS}_{0,05}$ & 0,247 & - & 0,054 & - & 0,247 & - \\
\hline
\end{tabular}

Mean from five replicate pots are given and different letters in the same column are significantly different at the level of 0.05 .

\section{Effect of salinity on chlorophyll concentration}

Salinity stress $(5,10$ and $15 \mathrm{~g} / \mathrm{l} \mathrm{NaCl})$ resulted in significantly progressive decline the photosynthetic pigments (chlorophyll a and b). Similarly, Chl b concentration decreased with $20 \%$ at $\mathrm{NaCl}$ concentrations of $5 \mathrm{~g} / \mathrm{l}$. Red variety had significantly more $\mathrm{Chl} \mathrm{a}$ and $\mathrm{Chl} \mathrm{b}$ than green variety at all $\mathrm{NaCl}$ concentrations. The strongest effect of salt occurred with two varieties between 10 and $15 \mathrm{~g} / \mathrm{l} \mathrm{NaCl}$. 


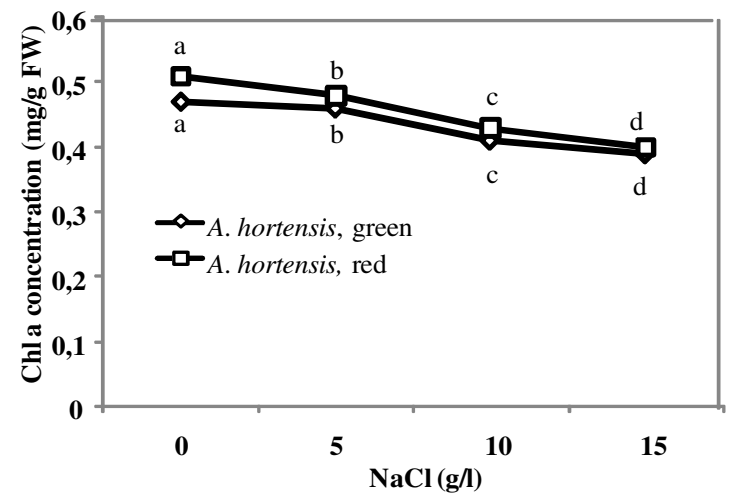

(a)

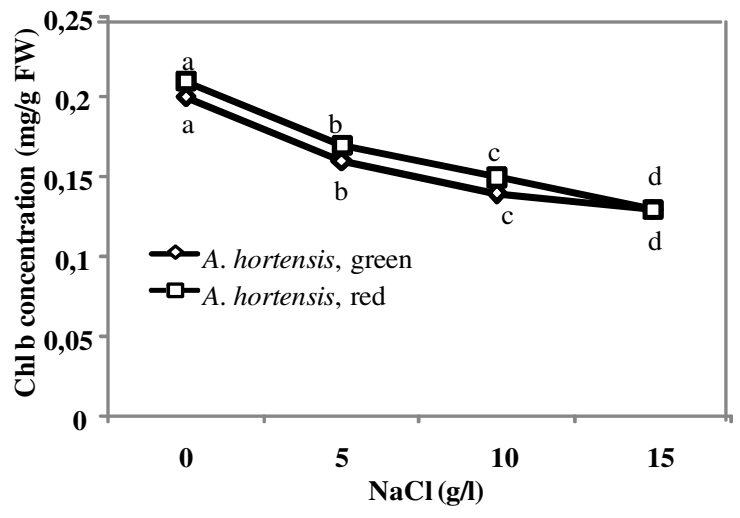

(b)

Figure 2. Effects of increasing $\mathrm{NaCl}$ concentration in the irrigation on chlorophyll a (a) and chlorophyll $b(b)$ in the two Atriplex varieties green and red.

\section{Effect of salinity on growth}

Plant height decreased with increasing salinity for the both varieties (Fig. 3a). Plant height decreased in the plants supplemented with $\mathrm{NaCl}$ and their rate of loss was proportional to the concentration of the $\mathrm{NaCl}$. Stem height decreased rapidly at $100 \mathrm{~cm}$ in $15 \mathrm{~g} / 1 \mathrm{NaCl}$ concentration for two varieties. The plant height of both varieties was nearly equal at all $\mathrm{NaCl}$ concentration, suggesting no difference in varietal response to $\mathrm{NaCl}$.

Increasing concentration of salt in soil significantly retarded $(\mathrm{p}<0.05)$ elongation of stems and roots (Fig. 3b). Root growth of two Atriplex varieties responded differently to increasing salinity. As salinity level increased from control $(0 \mathrm{~g} / \mathrm{l})$ to $(15 \mathrm{~g} / \mathrm{l})$, green variety exhibited a trend of increasing in root mass. In contrast, root elongation of red variety decreased linearly with increasing salinity. 


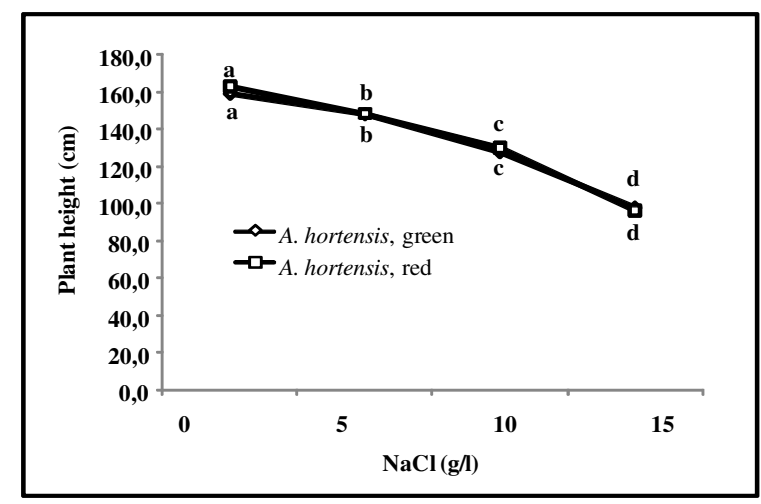

(a)

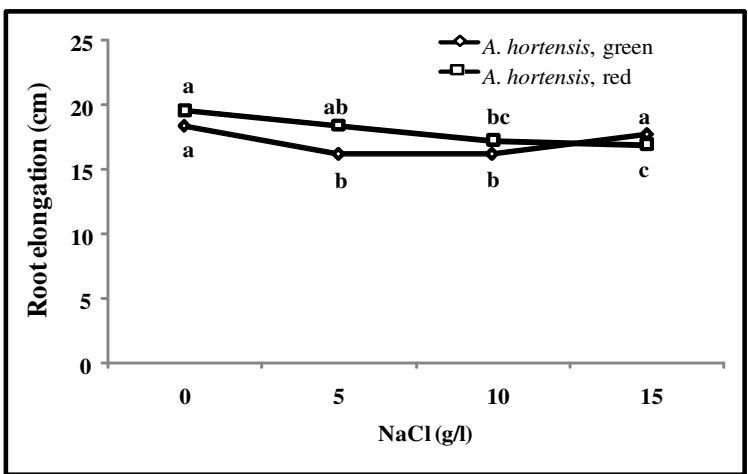

(b)

Figure 3. Effects of increasing $\mathrm{NaCl}$ concentration in the irrigation on plant height (a) and root elongation (b) in the two Atriplex varieties green and red

\section{Effect of salinity on water content}

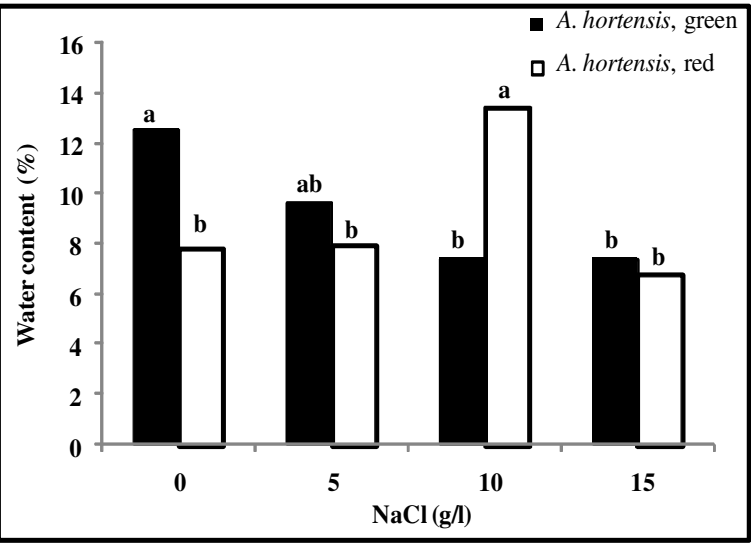

Figure 4. The effect of salinity on total leaf area in the two Atriplex varieties green and red. Different letters represent a significant difference $(P<0.05)$ between treatments

The water content of leaves of $A$. hortensis red variety was highest in plants grown at $10 \mathrm{~g} / \mathrm{l} \mathrm{NaCl}$, followed by the leaves grown at $5 \mathrm{~g} / \mathrm{l}$ and the lowest water content was in 
leaves grown at $15 \mathrm{~g} / \mathrm{l} \mathrm{NaCl}$ (Fig. 4). Further increase in salinity caused a reduction in water content to a very low value at higher salinities.

\section{Effect of salinity on stomatal conductance}

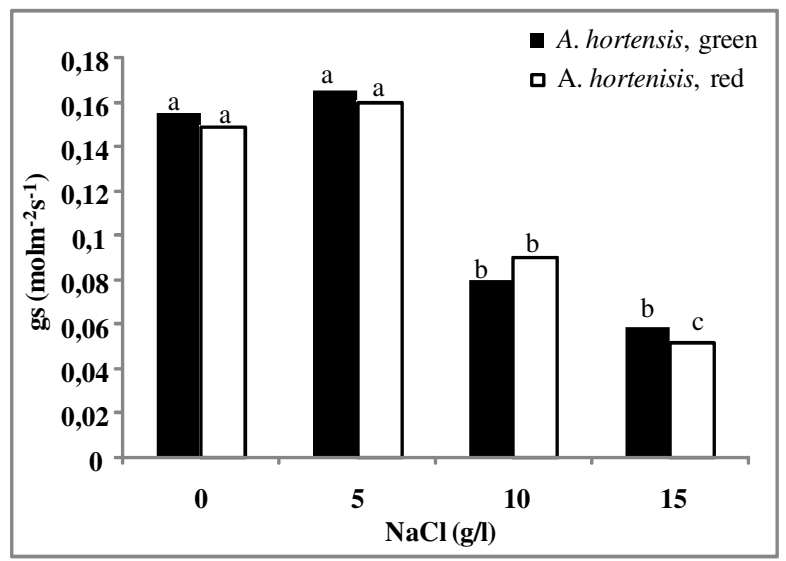

Figure 5. Effects of increasing $\mathrm{NaCl}$ concentration on stomatal conductance of the two Atriplex hortensis varieties green and red.

Stomatal conductance (Fig. 5) of both varieties decreased by about $50 \%$ with increasing external $\mathrm{NaCl}$ concentration. Mean stomatal conductance $(g \mathrm{~s})$ measures ranged from 0,16 molm $^{-2} \mathrm{~s}^{-1}$ in low salinity treatments up to $0,06 \mathrm{molm}^{-2} \mathrm{~s}^{-1}$ in high salinity treatments.

\section{Discussion}

Atriplex hortensis is highly tolerant of salinity. Halophytic Atriplex species show stimulation of growth at $\mathrm{NaCl}$ concentrations that are inhibitory to non-halophytes [77]. Saline soils and saline irrigations constitute a serious production problem for vegetable crops as saline conditions are known to suppress plant growth [87]. Increases in salinity lead to a reduction and/or delay in growth of both halophyte and glycophyte plants [37, $39,96]$. An important finding was that plants could survive at $15 \mathrm{~g} \mathrm{l}^{-1}$ salinity and this might be a suitable concentration to use to select highly salt-tolerant plants. Studies have shown that Atriplex spp., such as A. nummularia, A. griffithii and A. hortensis, could survive under highly saline conditions; with optimal growth occurring at 5 to 10 $\mathrm{gl}^{-1} \mathrm{NaCl}[41,82,101]$. Other researchers have not observed growth stimulation by $\mathrm{NaCl}$ in $S$. virginicus $[12,70,71]$.

Halophytes such as Atriplex spp. show a stimulation of growth at $\mathrm{NaCl}$ concentrations that are inhibitory to the growth of non-halophytes [77]. [3] showed that the growth of both Atriplex inflata F. Muell. and A. nummularia Lindl. was greater at $600 \mathrm{~mm} \mathrm{NaCl}$ than in nutrient controls. Atriplex spp. vary in their degree of salt tolerance [80]. Atriplex halimus L. had the least decrease in dry mass production (40\%) at $750 \mathrm{~mm} \mathrm{NaCl}$, whereas A. calotheca (Rafn.) Rafn. and Fries. (67\%) and A. nitens Schkuhr $(80 \%)$ had greater decreases but all three species were able to survive in this salt treatment [80]. [93] determined that A. spongiosa F. Muell. was able to grow in 
medium containing over $600 \mathrm{~mm} \mathrm{NaCl}$, with dry mass production decreasing by $50 \%$ at $800 \mathrm{~mm} \mathrm{NaCl}$. Other chenopod halophytes, such as Halosarcia pergranulata [91], Suaeda fruticosa [41] and Sarcocornia fruticosa [84], have growth optima at moderate to high salinities.

In general, low salinity levels do not appear to have a deleterious effect on the growth of Atriplex spp. and may actually stimulate growth [3, 15, 59]. Many species of Atriplex are valued as livestock forage when herbage availability is low especially in arid environments and salt-affected area [34] because they have high content of crude protein, vitamins (A, C and D) and minerals such as chromium $[61,86]$.

In this study we show that the presence of medium-high concentrations of $\mathrm{NaCl}$ in the growth solution induced more deleterious effects on growth. These results fit with those previously reported in Atriplex prostrata [21]. Most species tested had their maximum biomass production in low salinity treatments. These results broadly match those obtained by $[17,25,27,29,30,38]$ who reported that low $\mathrm{NaCl}$ concentrations stimulate growth of some halophytic species, but an excess of salt decreases growth and biomass production. [56] reported that in most halophytic species growth decreases gradually with the increase of salt rate in the culture medium above a critical threshold specific to each species. Reduction of plant growth under saline conditions is a common phenomenon [4] but such reduction occurs differently in different plant organs. For example, in the present experiment, root dry weight was reduced more than shoot dry weight by salt stress. In contrast, [35] observed that salt stress inhibited the growth of shoot more than root in Brassica species.

Succulence is anatomical adaptation, which, by increasing the vacuolar volume, permits the accumulation of large amounts of water and dissolved ions in both shoots and roots [68]. Exposure to salinity concentrations has been shown to increase the tissue water content of halophytes $[42,51]$. In halophytes, water content and the ability to make osmotic adjustments have been seen as important determinants of growth response $[9,10,46,58]$. In the present study salinity stress resulted in decreased chlorophyll content. Saline stress led to leaf chlorosis, which ultimately resulted in significant photoinhibition and photodestruction of chlorophyll pigments. Similar results have been reported for other legumes $[1,92,94]$.

The effect of salt stress on Atriplex leaf growth and shoot development is similar to its effect on sorghum [11] and lettuce [49]. Measurements of chlorophyll fluorescence provide quantitative information about photosynthesis through noninvasive means [98]. Salinity responses of chlorophyll a fluorescence have been studied in barley (Hordeum vulgare L.), [8, 48], rice (Oryza sativa L.), [54] and sorghum [53, 88, 89]. An increase in chlorophyll content has been thought to be due to the accumulation of $\mathrm{NaCl}$ in the chloroplast [43]. [65] also concluded that salt stress induced an increase in the chlorophyll content, which could be due to an increase in the number of chloroplasts in stressed leaves. The decreased in chlorophyll content under salinity stress is a commonly reported phenomenon and in various studies, because of its adverse effects on membrane stability [2,5]. [73] found that the chlorophyll content reduction of leaves started to occur in plants grown at $100 \mathrm{mM} \mathrm{NaCl}$ and higher concentrations. These reductions could be attributed to the effect of salinity that causes inhibition of synthesis of chlorophyll or accelerating its degradation [83].

In general, salinity can reduce plant growth or damage the plants through: (i) osmotic effect (causing water deficit), (ii) toxic effects of ions and (iii) imbalance of the uptake 
of essential nutrients. These modes of action may operate on the cellular as well as on higher organizational levels and influence all the aspects of plant metabolism [23, 45].

All these results agree with those previously reported for A. griffithii where the growth of plants cultivated in the absence or in the presence of $90 \mathrm{mM} \mathrm{Na}{ }^{+}$was similar even after 90 days [41]. Previous studies in Atriplex amnicola also indicated that this plant increased growth after additions of $\mathrm{NaCl}$ to the growth medium up to 25-50 $\mathrm{mM}$ but then growth declined as salt concentration was increased [6].

Results for reduction of shoot growth and leaf area development of A.hortensis with increasing salt concentration are in conformity with finding of [16], who reported that growth in Kenaf (Hibiscus cannabinus) under moderate salt stress was affected primarily through a reduction in elongation of stem and leaf area development.

There were very clear effects of $\mathrm{NaCl}$ on stomatal conductance in the present experiment, across the whole range of salinity similar to results published for $S$. pectinata by [32]. In other species, salinity decreases assimilation through reductions in leaf area [69, 79] and stomatal conductance [13, 78]. Exposure of halophytes to increasing salinity may result in partial closure of the stomata, in order to limit both transpiration and the transport of salts to the leaves [99]. Salinity is known to inhibit photosynthesis in a number of plant species $[19,22,52,103]$.

\section{Conclusion}

In summary our results show that A. hortensis is a highly salt tolerant annual halophyte, this plant has the ability to complete its life cycle under very high saline media. Their growth may be stimulated by the presence of salts in the growth medium. In conclusion, results presented here show that salinity reduces leaf growth and stomatal conductance variables. The remarkable reduction of total plant leaf area is likely to affect whole plant photosynthesis, contributing to the low biomass production. Chlorophyll fluorescence appears to be a useful indicator of salt stress at high $\mathrm{NaCl}$ concentrations. Finally, in this study, salinity stress results in a clear stunting of plant growth, which results in a considerable decrease in the dry weights of shoots and roots. Increasing salinity is accompanied also by significant reductions in stomatal conductance, plant height and root length. Increased research on the selection of halophytic species which have an economic utilization may enable the rehabilitation and revegetation of salt-affected lands given that the appropriate soil and irrigation management is applied.

\section{REFERENCES}

[1] Al-Khanjari, S, Al-Kathiri, A, Esechie, H.A. (2002): Variation in chlorophyll meter readings, nodulation and dry matter yields of alfalfa (Medicago sativa L.) cultivars differing in salt tolerance. - Crop Res. 24: 350-356.

[2] Al-Sobhi, O.A., Al-Zahrani, H.S., Al-Ahmadi, S.B. (2005): Effect of salinity on Chlorophyll \& carbohydrate contents of Calotropis procera seedlings. - King Fasil University J. (Accepted, in press).

[3] Ashby, W.C., Beable, N.C.W. (1957): Studies in halophytes. Salinity factors in the growth of Australian salt bushes. - Ecology 38: 344-352.

[4] Ashraf, M., Harris, P.J. (2004): Potential biochemical indicators of salinity tolerance in plants. - Plant Sci. 166: 3-16. 
[5] Ashraf, M.Y., Bhatti, A.S. (2000): Effect of salinity on growth and chlorophyll content in rice. - Pak. J. Ind. Res. 43: 130-131.

[6] Aslam, Z., Jeschke, W.D., Barrett-Lennard, E.G., Setter, T.L., Watkin, E., Greenway, H. (1986): Effects of external $\mathrm{NaCl}$ on the growth of Atriplex amnicola and the ion relations and carbohydrate status of leaves. - Plant. Cell. Environ. 9: 571-580.

[7] Bajji, M., Kinet, J.M., Lutts, S. (1998): Salt stress effects on roots and leaves of Atriplex halimus L. and their corresponding callus cultures. - Plant. Science 137: 131-42.

[8] Belkhodja, R., Morales, F., Abadia, A., Gomez-Aparisi, J., Abadia, J. (1994): Chlorophyll fluorescence as a possible tool for salinity tolerance screening in barley (Hordeum vulgare, L.). - Plant Physiol. 104: 667-673.

[9] Ben Amor, N., Ben Hamed, K., Debez, A., Grignon Abdelly, C. (2005): Physiological and antioxidant responses of the perennial halophyte Crithmum maritimum to salinity. Plant. Sci. 168: 889-899.

[10] Benlloch-Gonzalez, M., Fournier, J.M., Ramos, J., Benlloch, M. (2005): Strategies underlying salt tolerance in halophytes are present in Cynara cardunculus. - Plant. Sci. 168: 653-659.

[11] Bernstein, N., Lauchli, A., Silk, W.K. (1993a): Kinematics and dynamics of sorghum (Sorghum bicolor L.) leaf development at various $\mathrm{Na} / \mathrm{Ca}$ salinities: I. Elongation growth. - Plant. Physiol. 103: 1107-1114.

[12] Blits, K.C., Gallagher, J.L. (1991): Morphological and physiological responses to increased salinity in marsh and dune ecotypes of Sporobolus virginicus (L) Kunth. Oecologia 87: 330-335.

[13] Brugnoli, E., Lauteri, M. (1991): Effects of salinity on stomatal conductance, photosynthetic capacity, and carbon isotope discrimination of salt-tolerant (Gossypium hirusutum L.) and salt-sensitive (Phaseolus vulgaris L.) C3 non-halophytes. - Plant. Physiology. 95: 628-635.

[14] Cabello-Hurtado, F., Ramos, J. (2004): Isolation and functional analysis of the glycerol permease activity of two nodulin-like intrinsic proteins from salt stressed roots of the halophyte Atriplex nummularia. - Plant. Science 166: 633-640.

[15] Chatterton, N.J., McKell, C.M. (1969): Atriplex polycarpa. I. Germination and growth as affected by sodium chloride in water cultures. - Agronomy J. 61: 451-453.

[16] Curtis, P.S., Lauchli, A. (1986): The role of leaf area development and photosynthetic capacity in determining growth of kenaf under moderate salt stress. - Austral. J. Plant Physiol 13: 553-565.

[17] Daoud, S., Koyro, H-W., Harrouni, M.C. (2001): Salinity tolerance of beta vulgaris ssp. Maritima. I. Biomass production and osmotic adjustment. (to appear in H. Lieth, Ed. "Cash Crop halophytes : Potentials, pilot Projects, Basic and Applied Research on Halophytes and saline irrigation. - "Ten years after the Al Ain meeting" T:VS Series, Kluwer academic publishers group (the Netherlands).

[18] Debez, A., Hamed, K.B., Grignon, C., Abdelly, C. (2004): Salinity effects on germination, growth, and seed production of the halophyte Cakile maritime. - Plant and soil 262: 179-189.

[19] Dionisio-Sese, M.L., Tobita, S. (2000): Effects of salinity on sodium content and photosynthetic responses of rice seedlings differing in salt tolerance. - Journal of Plant Physiology 157: 54-58.

[20] Donahue, R.L., Miller, R.W., Shickluna, J.C. (1983): Soils: An Introduction to Soils and Plant Growth. - Englewood Cliffs, New Jersey, Prentice-Hall.

[21] Egan, T.P., Ungar, I.A. (1998): The effect of different salts of sodium and potassium on the growth of Atriplex prostrate (Chenopodiaceae). - J. Plant Nutr. 21: 2193-2205.

[22] Flowers, T.J., Yeo, A.R. (1981): Variability in the resistance of sodium chloride salinity within rice (Oryza sativa L.) varieties. - New Phytologist 88: 363-373.

[23] Garg, B.K., Gupta, I.C. (1997): Saline Wastelands Environment and Plant Growth. Jodhpur: Scientific Publishers. 
[24] Gihad, E.A., El Shaer, H.M. (1992): Utilization of halophytes by livestock on rangelands: problems and prospects. In: V.R, Squires and A.T., Ayoub (Editors), Halophytes as a Resource for Livestock and for Rehabilitation of Degraded Lands. - Kluwer Academic, Dordrecht, pp. 77-96.

[25] Glenn, E., O'Leary, J.W. (1984): Relationship between salt accumulation and water content of dicotyledonous halophytes. - Plant. Cell. Environment. 7:253-261.

[26] Glenn, E., Pfister, R., Brown, J., Thompson, T., O'Leary, J. (1996): Na and K accumulation and salt tolerance of Atriplex canescens (Chenopodiaceae) genotypes. American Journal of Botany. 83: 997-1005.

[27] Gorham, J. (1996): Mechanism of salt tolerance of halophytes. - In: Choukr-Allah R, Malcolm CV, Hamdy A, eds. Halophytes and biosaline agriculture. New York: Marcel Dekker, Inc., 31-53.

[28] Greenway, H. (1968): Growth stimulation by high chloride concentrations in halophytes. - Israel Journal of Botany 17: 169-177.

[29] Harrouni, M.C., Daoud, S., Koyro, H-W. (2001): Effect of seawater irrigation on biomass production and ion composition of 7 halophytic species in Morocco. (to appear - in: H. Lieth, Ed. "Cash Crop halophytes : Potentials, pilot Projects, Basic and Applied Research on Halophytes and saline irrigation. Ten years after the Al Ain meeting" T:VS Series, Kluwer academic publishers group, the Netherlands).

[30] Harrouni, M.C., Daoud, S., El Alami, A., Debbagh, B., Chokr-Allah, R., Bengaddour, R. (1999): Responses of some halophytes to seawater irrigation in Morocco. Halophyte uses in different climates II, pp. 57-75. Edited by A. Hamdy, H. Lieth, M. Todorovic and M. Moschenko.

[31] Hasegawa, P.M., Bressan, R.A., Zhu, J.K., Bohnert, H.J. (2000): Plant cellular and molecular responses to high salinity. - Annu. Rev. Plant Physiol. Mol. Biol. 51: 463-499.

[32] Heckathorn, S.A., Delucia, E.H. (1991): Effect of leaf rolling on gas exchange and leaf temperature of Andropogon gerardii and Spartina pectinata. - Bot. Gaz. 152: 263-268.

[33] Hopkins, D.L., Nicholson, A. (1999): Meat quality of Squires, V. R. and A. L. Ayoub, 1992. Halophytes as a wether lambs grazed on saltbush (A. nummularia) plus supplements or Lucerne (Medicago sativa). - Meat Sci. 51: 91-95.

[34] Houerou, H.N.K., Le Houerou, H.N., Choukr, Allah R., Malcolm, C.V., Hamdy, A. (1995): Forage halophytes in the Mediterranean Basin. Halophytes and Biosaline Agricultures: 115-136, isolation of antifungal proteins and peptides. - Pak. J. Bot. 39 (1): 211-221.

[35] Jamil, A., Shahid, M., Khan, M.M., Ashraf, M. (2007): Screening of some medicinal plants for

[36] Jefferies, R.L. (1981) Osmotic adjustment and the response of halophytic plants to salinity. - Bio Science 31(1): 42-46.

[37] Katembe, W.J., Ungar, I.A., Mitchell, J.P. (1998): Effect of salinity on germination and seedling growth of two Atriplex species (Chenopodiaceae). - Ann of Botany 82: 167-175.

[38] Kelly, P.M., Jones, P.D., Sear, C.B., Cherry, B.S.G., Tavakol, R.K. (1982): Variations in surface air temperatures: Part 2. Arctic regions 1881-1890. - Monthly Weather Review 110: 71-83.

[39] Khan, M.A., Ungar, I.A. (1984): The effect of salinity and temperature on germination of polymorphic seeds and growth of Atriplex triangularis. - Am. J. of Botany 71: 481-489.

[40] Khan, M.A., Duke, N.C. (2001): Halophytes - A resource for the future. - Wetlands Ecolo. Manag. 6: 455-456.

[41] Khan, M.A., Ungar, I.A., Showalter, A.M. (2000): Effects of salinity on growth, water relations and ion accumulation of the subtropical perennial halophyte, Atriplex griffithii var. stocksii. - Ann. Bot. 85: 225-232.

[42] Khan, M.A., Ungar, I.A., Showalter, A.M. (2005): Salt stimulation and tolerance in an intertidal stem-succulent halophyte. - J. Plant Nutri. 28: 1365-1374. 
[43] Kirst, G.O. (1989): Salinity tolerance of eukaryotic marine algae. - Annu Rev Plant Physiol Plant Mol Biol 40: 21-53

[44] Koyro, H.W. (2006): Effect of salinity on growth, photosynthesis, water relations and solute composition of the potential cash crop halophyte Plantago coronopus (L.). Environ. Exp. Bot. 56: 136-146.

[45] Kramer, P.J. (1983): Water Relations of Plants. - New York, Academic Press.

[46] Kurkova, E.B., Kalinkina, L.G., Baburina, O.K., Myasoedov, N.A., Naumova, T.G. (2002): Responses of Seidlitzia rosmarinus to salt stress. - Biol. Bull. 29(3): 221-228.

[47] Laeuchi, A., Luettge, U. (2002): (Eds.) Salinity. - Kluwer Academic Publishers, Dordrecht, Neth., p. 341.

[48] Larcher, W., Wagner, J., Tammathaworn, A. (1990): Effects of superimposed temperature stress on in vivo chlorophyll fluorescence of Vigna unguiculata under saline stress. - J. Plant Physiol 136: 92-102

[49] Lazof, D., Bernstein, N., Laüchli, A. (1991): Growth and development of the Lactuca sativa shoot as affected by $\mathrm{NaCl}$ stress: consideration of leaf developmental stages. - Bot. Gaz. 152: 72-76.

[50] Le Houérou, H.N. (2000): Utilization of fodder trees and shrubs in the arid and semiarid zones of west Asia and north Africa. - Arid Soil Resear. Rehab. 14: 101-135.

[51] Lee, G., Carrow, V., Duncan, A. (2005): Growth and water relation responses to salinity stress in halophytic sea shore Paspalum ecotypes. - Sci. Hort. 104: 221-236.

[52] Longstreth, D.J., Nobel, P.S. (1979): Salinity effects on leaf anatomy. - Plant Physiology 63: 700-703.

[53] Lu, C., Zhang, J. (1998): Thermostability of photosystem II is increased in salt-stressed sorghum. - Aust. J. Plant Physiol. 25: 317-324.

[54] Lutts, S., Kinet, J.M., Bouharmont, J. (1996): NaCl-induced senes cence in leaves of rice (Oryza sativa,L.) cultivars differing in salinity resistance. - Ann. Bot. 78: 389-398.

[55] Lutts, S., Lefèvre, I., Delpe're'e, C., Kivits, S., Dechamps, C., Robledo, A., Correal, E. (2004): Heavy metal accumulation in the halophyte species Mediterranean saltbush. Journal of Environmental Quality 33: 1271-1279.

[56] Maas, E.V., Grieve, C.M. (1987): Sodium induced calcium deficiency in salt-stressed corn. - Plant Cell and Environment 10: 559-564.

[57] Maas, E.V., Hoffman, G.J. (1977): Crop salt tolerancecurrent assessment. - Journal of Irrigation Drainage Division ASCE 103: 115-134.

[58] Maggio, A., Reddy, M.P., Joly, R.J. (2000): Leaf gas exchange and solute accumulation in the halophyte Salvadora persica grown at moderate salinity. - Environ. Exp. Bot. 44: 31-38.

[59] Matoh, T., Watanabe, J., Takahashi, E. (1986): Effects of sodium and potassium salts on the growth of a halophyte Atriplex gmelini. - Soil Science and Plant Nutrition 32: 451459.

[60] McArthur, E.D., Sanderson, S.C. (1984): Distribution, systematics, and evolution of Chenopodiaceae: an overview: - In: Tiedemann, A.R., McArthur, E.D., Stutz, H.C., Stevens, R., Johnson, K.L., comps. Proceedings, Symposium on the Biology of Atriplex and Related Chenopods. Gen. Tech. Rep. INT-172. 1983 May 4B6; Provo, UT. Ogden, UT: USDA Forest Service, Intermountain Forest and Range Experiment Station: 14B23.

[61] McKell, C.M. (1989): The biology and utilization of shrubs. - San Diego, CA: Academic Press, Inc. 656 p.

[62] McKell, C.M. (1994): Salinity tolerance in Atriplex species : Fodder shrubs of arid lands. - In: Pessarakli P, ed. Handbook of plant and crop stress. New York, Marcel Dekker, Inc., 497-503.

[63] Mer, G., Bochkarev, A., Gupta, R., Bochkareva, E., Frappier, L., Ingles, C.J., Edwards, A.M., Chazin, W.J. (2000): Structural basis for the recognition of DNA repair proteins UNG2, XPA, and RAD52 by replication factor RPA. - Cell 103: 449-456 
[64] Metzner, R., Litwin, G., Weil, G. (1965): The relation of expectation and mood to psilocybin reactions: a questionnaire study. - Psychedelic Rev. 5: 3-39.

[65] Misra, V.N., Shinde, V., Mohanty, R.K., Pandey, L., Kharakwal, J. (1997): - Man and Environment 32: 35.

[66] Mozafar, A., Goodin, J.R., Oerlti, J.J. (1970): Sodium and potassium interactions in increasing the salt tolerance of Atriplex halimus L. II. Nan and K+ uptake characteristics. - Agron J 62: 478-481.

[67] Munns, R. (1993): Physiological processes limiting plant growth in saline soils: some dogmas and hypotheses. - Plant Cell and Environment 16: 15-24.

[68] Munns, R. (2002): Comparative physiology of salt and water stress. - Plant Cell Environ. 25: 239-250.

[69] Munns, R., Guo, J., Passiora, J.B., Cramer, G.R. (2000): Leaf water status controls daytime but not daily rates of leaf expansion in salt-treated barley. - Australian Journal of Plant Physiology 27: 949-957.

[70] Naidoo, G., Naidoo, Y. (1998): Salt tolerance in Sporobolus virginicus: the importance of ion relations and salt secretion. - Flora 193: 337-344.

[71] Naidoo, G., Mundree, S.G. (1993): Relationship between morphological and physiological responses to waterlogging and salinity in Sporobolus virginicus (L.) Kunth. - Oecologia 93: 360-366.

[72] Nedjimi, B., Daoud, Y., Touati, M. (2005): Culture in vitro of Algierian halophyte (Atriplex halimus subsp. schweinfurthii) in presence of $\mathrm{NaCl}$. - Proc. of International Congress on Improvement of Vegetable Production, Algeria. 143-144 (in French).

[73] Netondo, G.W., Onyango, J.C., Beck, E. (2004): Sorghum and salinity: I. Response of growth, water relations, and ion accumulation to $\mathrm{NaCl}$ salinity. - Crop Sci. 44: 797-805.

[74] Neumann, P. (1997): Salinity resistance and plant growth revisited. - Plant Cell Environ. 20:1193-1198.

[75] Ortiz-Dorda, J., Martinez-Mora, C., Correal, E., Simon, B., Cenis, J.L. (2005): Genetic structure of Atriplex halimus populations in the mediterranean basin. - Ann. Bot. 95: 827-834.

[76] Osman, A.E., Ghassaeli, F. (1997): Effects of Storage conditions and presence of fruiting bracts on the germination of Atriplex halimus and Salsola Vermiculata. - Exp. Agri 33: 149-155.

[77] Osmond, C.B., Bjorkman, O., Anderson, D.J. (1980): Physiological processes in plant ecology. Toward a synthesis with Atriplex. - New York, Springer-Verlag.

[78] Ouerghi, Z., Cornie, G., Roudani, M., Ayadi, A., Brulfert, J. (2000): Effect of $\mathrm{NaCl}$ on the photosynthesis of two wheat species (Triticum durum and Triticum aestivum) differing in their sensitivity to salt stress. - Journal of Plant Physiology 15: 519-527.

[79] Papp, J.C., Ball, M.C., Terry, N. (1983): A comparative study of the effects of $\mathrm{NaCl}$ salinity on respiration, photosynthesis, and leaf extension growth in Beta vulgaris L. (sugar beet). - Plant Cell Environ 6: 675-677.

[80] Priebe, A., Jaeger, H.J. (1978): Ein $^{-}$uss von $\mathrm{NaCl}$ auf waschstum und ionengehalt unterschiedlich saltztolerater $\mathrm{P}^{-}$anzen. - Angewandte Botanik 52: 531-541.

[81] Ramoliya, P.J., Patel, H.M., Pandey, A.N. (2004): Effect of salinization of soil on growth and macro and micro nutrient accumulation in seedlings of Acacia catechu (Mimosaceae). - Annals of Applied Biology 144: 321-332.

[82] Ramos, J., Lopez, M.J., Benlloch, M. (2004): Effect of $\mathrm{NaCl}$ and $\mathrm{KCl}$ salts on the growth and solute accumulation of the halophyte Atriplex nummularia. - Plant and Soil 259: 163-168.

[83] Reddy, M.P., Vora, A.B. (1986): Changes in pigment composition, Hill reaction activity and saccharides metabolism in Bajra (Pennisetum typhoides $\mathrm{S} \& \mathrm{H}$ ) leaves under $\mathrm{NaCl}$ salinity. - Photosynthetica 20: 50-55. 
[84] Redondo-Gómez, S., Wharmby, C., Castillo, J.M., Mateos-Naranjo, E., Luque, C.J., de Cires, A. (2006): Growth and photosynthetic responses to salinity in an extreme halophyte, Sarcocornia fruticosa. - Physiologia Plantarum 128: 116-124.

[85] Richardson, S.G., McKell, C.M. (1980): Water relations of Atriplex canescens as affected by the salinity and moisture percentages of processed oil shale. - Agronomy Journal 72: 946-950.

[86] Shani, J., Ahronson, Z., Sulman, F.G. (1972): Insulin-potentiating effect of saltbush (Atriplex halimus) ashes. - Isr. J. Med. Sci. 8: 757-758.

[87] Shannon, M.C., Grieve, C.M. (1999): Tolerance of vegetable crops to salinity. - Sci. Hortic. 78(1/4): 5-38.

[88] Sharma, P.K., Hall, D.O. (1991): Interaction of salt stress and photoinhibition on photosynthesis in barley and sorghum. - J. Plant Physiol. 138: 614-619.

[89] Sharma, P.K., Hall, D.O. (1992): Changes in carotenoid composition and photosynthesis in barley and sorghum . - J. Plant Physiol. 140: 661-666.

[90] Shen, Z., Denton, M., Mutti, N., Pappan, K., Kanost, M.R., Reese, J.C., Reeck, G.R. (2003): Polygalacturonase from Sitophilus oryzae: Possible horizontal transfer of a pectinase gene from fungi to weevils. 9pp. - Journal of Insect Science 3: 24.

[91] Short, D.C., Colmer, T.D. (1999): Salt tolerance in the halophyte Halosarcia pergranulata subsp. pergranulata. - Annals of Botany 83: 207-213.

[92] Soussi, M., Ocaña, A., Lluch, C. (1998): Effects of salt stress on growth, photosynthesis and nitrogen fixation in chick-pea (Cicer arietinum L.). - Journal of Experimental Botany 49: 1329-1337.

[93] Storey, R., Wyn Jones, R.G. (1979): Quaternary ammonium compounds in plants in relation to salt resistance. - Phytochemistry 16: 447-451.

[94] Sudhakar, G., Jyothi, B., Venkateswarlu, V. (1991) Metal pollution and its impact on algae in flowing waters in India. - Archives of Environmental Contamination and Toxicology 21: 556-566.

[95] Uchiyama, Y. (1987): Salt tolerance of Atriplex nummularia. - Technical Bulletin Tropical Agricultural Research Center Japan 22: 1-69.

[96] Ungar, I.A. (1982): Germination ecology of halophytes. - In: Sen DN, Rajpurohit KS, eds. Contributions to the ecology of halophytes. The Hague: Dr. W. Junk Publishers, 143154.

[97] Ungar, I.A. (1996): Effect of salinity on seed germination, growth and ion accumulation of Atriplex patula (Chenopodiaceae). - American Journal of Botany 83: 604-607.

[98] van Kooten, O., Snel, J.F.H. (1990): The use of chlorophyll fluorescence nomenclature in plant stress physiology. - Photosynth. Res. 25: 147-150.

[99] Véry, A.A., Robinson, M.F., Mansfield, T.A., Sanders, D. (1998) Guard cell cation channels are involved in $\mathrm{Na}^{+}$-induced stomatal closure in a halophyte. - Plant Journal 14: 509-521.

[100] Wang, L.W., Showalter, A.M. (2004): Cloning and salt-induced, ABA independent expression of choline mono-oxygenage in Atriplex prostrata. - Physiologia Plantarum 120: 405-412.

[101] Wilson, C., Lesch, S.M., Grieve, C.M. (2000): Growth stage modulates salinity tolerance of New Zealand spinach (Tetragonia tetragonioides, Pall.) and red orach (Atriplex hortensis L.). - Ann. Bot. 85: 501-509.

[102] Yeo, A.R. (1998): Molecular biology of salt tolerance in the context of whole-plant physiology. - J. Exp. Bot. 49: 915-929.

[103] Yeo, A.R., Capon, S.J.M., Flowers, T.J. (1985): The effect of salinity upon photosynthesis in rice (Oryza sativa L.): gas exchange by individual leaves in relation to their salt content. - Journal of Experimental Botany 36: 1240-1248.

[104] Zid, E., Boukharis, M. (1977): Quelques aspects de la tolerance de l'Atriplex halimus L. au chlourure de sodium. - Oecologia Plantarum 12: 351-362. 